\title{
Articles
}

Central European Review of Economics \& Finance

Vol. 21, No. 5 (2017), pp. 59-74. D0l: 10.24136/ceref.2017.022

Magdalena Zwierzchowska ${ }^{1}$

\section{BENEFITS RESULTING FROM THE IMPLEMENTATION OF THE CORPORATE SOCIAL RESPONSIBILITY}

The paper presents benefits resulting from the implementation of the Corporate Social Responsibility by observing guidelines included in ISO 26000:2010 standard according to the studies carried out by the Association Responsible Business Forum and KPMG an audit and advisory company. We presented the methodology of the studies undertaken by the organization mentioned above which analyzed the condition of the CSR in Poland. The same studies are carried out every year and special reports are drawn up based on their results which are described in detail together with a commentary comparing the current state of affairs with the previous year. The results of these measurements allow to check whether the CSR idea becomes more popular and more frequently applied and whether it brings measurable benefits both to the companies and their surroundings.

JEL Classification Codes: M14, D21.

Keywords: Corporate Social Responsibility, ISO 26000, benefits, Responsible Business, Forum, KPMG.

\section{Introduction}

Dynamic changes observed these days, especially the ones taking place in the system area, have placed enterprises in the entirely new surroundings and thus they were forced to conduct their business activity in the light of constantly growing competition. Today, both the already established compa-

\footnotetext{
${ }^{1}$ M.A. Ph.D. student, K. Pulaski University of Technology and Humanities in Radom, Poland, Faculty of Economic and Legal Sciences.
} 
nies and those entering in the market struggle to gain profit and reduce costs in particular in the view of the ongoing and unlimited social and economic development. Constantly developing technology contributed not only to the improvement of the conditions of living but it has also influenced the worsening of the condition of the natural environment. This situation demonstrates that the decisions made by each enterprise operating in the market are shaping its surroundings composed of the environment and its society.

In connection with the above, in 2010 the International Organization for Standardization worked out ISO 26000 standard which covers the guidelines related to the running of a socially responsible corporation. In other words, it shows how significant are the decisions made in respect of the nature of company's activity and how these decisions influence not only the economic aspect of this particular enterprise but above all its surroundings. Nowadays there are several definitions characterising the issue of the Corporate Social Responsibility (CSR), however the most frequently applied explanation of the term CSR is included in the ISO 26000 standard: „... it is an obligation of an organization to include social and environmental aspects in the decision making process and to take the responsibility for the influence of the decisions made and of the activities taken on the society and the environment" (ISO 26000:2010). This standard is not obligatory and its introduction is not certified. The companies respecting the rules of the ISO 26000 standard should bear in mind the social, economic and legal areas and the most important thing is to respect human rights and maintain the appropriate labour relations. The aspect of the management of human resources is also vital. The employees constitute the core of a company and they work for its success in the market. The appropriate functioning of an organization depends on their engagement, knowledge, qualifications and values (CIOP 2017, Gableta 2006, ISO 2600:2010, PKN 2013).

CSR indicates values that should be respected by an organization:

1. Organizational order.

2. Human rights.

3. Labour relations.

4. Natural environment protection.

5. Relations with consumers.

6. Social engagement (Zuzek 2012). Introducing ISO 26000 to the organization may have an impact on among others:

- Competition superiority and reputation;

- Ability to recruit and keep employees, customers, users; 
- Sustention of morality, engagement and efficiency of employees;

- Evaluation made by investors, donors, sponsors, financial markets;

- Relations with entrepreneurs, governments, media, suppliers, contractors, customers and society in which the organization is operating (PKN 2013).

Corporate responsibility is an effective management strategy and thanks to the social dialogue held at the local level it, contributes to the increase of competitiveness of enterprises at the global level. It also shapes beneficial conditions for the balanced economic and social development. Positive effects of the corporate social responsibility exerted on the competitiveness in the enterprise are connected with the improvement of the quality of the products, stronger loyalty of the customers and most importantly greater satisfaction of the customers. Moreover, positive image of a company means a better position in the labour market, easier cooperation with business partners and national administration. On the other hand, thanks to the above, the company has an easier access to the public funds. Also higher motivation and loyalty of company's employees translates into greater competitiveness in the enterprise. All these elements build positive image of a company (Odpowiedzialna Firma 2017)

The purpose of this study is to present the essence of the Corporate Social Responsibility for the enterprises operating in the market and functioning according to the CSR concept and treating the CSR concept as the aspect determining a lasting success. In the article we analysed the benefits resulting from the implementation of the CSR on the basis of the studies carried out by the Responsible Business Forum and KPMG at the turn of the year 2014 and 2015 in the companies performing their mission based on one of the pillars of balanced development - the idea of the CSR.

\section{Benefits of introducing CSR}

Proceeding to the benefits that could be gained by a company by way of introducing CSR, we have to mention the areas of this concept in order to specify the criterion of the division of these benefits in the further part of this paper. The CSR concept is manifested in the economic, social and ecological spheres which are at the same time connected with the benefits being the consequence of the introduction of the CSR. 
Economic area of introducing CSR rules covers:

1. Production stage including:

- A decision made by the highest-level management on the production of goods and packaging posing no threat towards the consumers safety and natural environment;

- The highest-level management declares a total compliance of its goods and services with the standards;

- A company observes specified standards;

- The highest-level management declares systematic and constant control over the influence exerted on the surroundings by the operation of a company;

2. Human resources management:

- Application of the equal opportunities policy;

- Implementation of programs and ethical codes;

- Equal pay;

- Provision of additional forms of health and social care;

- Support of laid-off employees;

3. Stakeholders:

- Fair competition;

- Ethical behavior in transactions with clients;

- Participation in charity, educational and quality-promoting initiatives;

- Introduction of loyalty programs supporting the maintenance of contacts with stakeholders;

- Thorough consideration of complaints.

Social area includes:

1. Cooperation with non-governmental organizations and local partners.

2. Social investments.

3. Combating bribery.

4. Observing human rights and customs of the local society.

5. Engaging company in various kinds of initiatives. In the ecological area, a company:

1. Realizes programs supporting the management of the influence on the natural environment,

2. Engages in ecological campaigns which promote the idea of balanced development,

3. Contributes to the protection of natural resources and uses renewable sources of energy,

4. Limits contamination and degradation of the environment (ISO 26000:2010). 
When implementing CSR, a company must take into account the financial, material, human and time outlays, thus it is very often wrongly perceived by an enterprise as an additional cost that contributes to the reduction of financial effectiveness. However CSR should be considered as an investment which is beneficial in the view of the areas described above, both in short and long periods of time. In addition, in order to analyse all benefits in a better way, it is worth becoming familiar with the tools applied by a company in the process of the management of social responsibility. The said tools include: social campaigns, ethical programs for employees, socially engaged marketing, corporate supervision, eco-labelling, socially responsible investments. By applying the above mentioned tools skilfully, an enterprise positively affects the functioning of its own business activity which is manifested through the benefits resulting from the CSR concept:

1. Increase of the interest of the investors - a particularly important group of external investors for a resiliently developing company are the creditors who grant loans for a different types of investments or innovations. That is why it is important that the management creates the image of its enterprise as a socially responsible enterprise by means of a reliable and transparent financial reporting and maintenance of partner relations with the surrounding.

2. Increase of the loyalty of the consumers and stakeholders - currently the awareness of the consumers is constantly growing when it comes to the social, ecological and economic areas. When they buy products, they pay attention not only to the price, but above all to the information concerning the producer, ecological aspects of purchased products and whether a given enterprise applies the rules of social responsibility. The above mentioned aspects create the image of a company and trust of the customers to a given brand.

3. Improvement of the relations with society and local authorities - a company by taking part in the everyday life of a local society, solving its problems or by taking up long-term social investment which bring measurable benefits develops uncontested relations with both the local society and self-government authorities.

4. Increasing competitiveness - nowadays with numerous companies functioning in the market that are operating in the same branches of industry, it is important for a given company to have an advantage guaranteeing competitive superiority. A CSR concept assures superiority not only in respect of the local and national consumers, but it also supports an enterprise in competing in the international or even global area. 
5. Increasing the level of organizational culture - a company which applies the rules of CSR crates and implements the standards of conduct towards the stakeholders aiming to avoid wrong partnership. This influences the creation of the company's culture based on trust, transparency and responsibility for all those interested in the company's success and its functioning.

6. Shaping a positive image of a company in the eyes of the employees - by numerous social campaigns, ethical codes and caring for the environment, the image of a company is improved not only in the eyes of the society, but also in the eyes of the employees who are the core of each organization. Thanks to such activities taken up by a company, the employees grant greater approval for it and moreover they have stronger motivation to work in more effective way bearing in mind their personal contribution to the positive image of the company.

7. Recruiting and keeping the best employees - the image of a socially responsible company strengthens trust and attractiveness in the labour market, while this attracts new employees and keeps the best ones (MDG 2014).

CSR is a pattern of the running a company in respect of the surroundings thus the benefits should be considered in terms of the society:

1. Partner relations and alliance - cooperation based on trust, respect and common business, a company should reject stiffness and formality of contacts for the benefit of flexible, open and honest communication which simplifies the partnership with clients, suppliers and even competitors.

2. Educating the society - acting in line with CSR rules, a company together with its conduct, promotes these standards in the area of business, setting the example for trade partners and competitive companies. It is also the knowledge passed to the citizens on the sustained development, fair competition, caring for the environment and respect for human rights.

3. Solving problems of the natural environment protection - a company realizes ecological programs of the protection of the natural environment contributing to the improvement of the condition of the environment and reduction of contamination and waste of the natural resources as well as the rational use of raw materials. Moreover, the enterprises engage in various kinds of ecology-friendly campaigns and promote the idea of balanced development increasing at the same time the ecological awareness of the society.

4. Combating poverty - a chance for the poor part of the society for development, finding a job and keeping it. 
5. Access to the information about the company - an enterprise which introduced CSR publishes its achievements in the form of a social report available for all stakeholders, carries out external audits and presents specific performance of a company in the area of ecology, society and economy.

6. Respect for the human rights - a company works out and introduces ethical codes, training and responsible human resources management bearing in mind the observance of human rights (CIOP 2017).

The employees of a company conducting a socially responsible business also benefit from the fact of their employment. It is commonly known that the core of the activity of a company is not attributed to the money but to the personnel which, when managed in appropriate way, works together for the success of the entire organization. Due to its engagement supported by appropriate motivation, it increases the effectiveness and profitability of a given business entity. Thus the activities of CSR cover the following benefits for the employees:

1. Increase of pay.

2. Employment safety.

3. Good internal communication.

4. Satisfaction of work and professional development.

5. Timeliness of pay.

6. Social benefits.

7. Bonus payments for effective and efficient work.

8. Less accidents at work (Gadomska-Lila 2012).

Introduction of CSR in the strategy of a business activity may bring numerous benefits connected either with savings (decrease of fees, reduction of the use of raw materials) or with the increase of employees satisfaction or safety of the functioning of an organization. The fact of the application of CSR may be also used for the marketing purposes (company promotion, increased competitiveness). However, these benefits may contribute to the improvement of the image of an organization but may also become the basis for the reduction of costs, innovative activities and positively influence the surroundings (caring for the natural environment). However it is worth mentioning that the CSR concept is inseparably connected with the stakeholders' concept. Due to the division of the stakeholders into the internal and external stakeholders, the benefits resulting from CSR have also been divided in two categories: internal and external ones. In the first case they are directly connected with the activities taken by an enterprise in order to satisfy the needs and expectations of the employees which may be visible in the 
sphere beyond an organization. Whereas the external benefits are connected with the external aspect (clients, business partners, social environment and public and national administration entities). The above described division is presented in the table 1.

Table 1. Internal and external benefits

\begin{tabular}{|c|c|}
\hline Internal benefits & External benefits \\
\hline $\begin{array}{l}\text { - Increase of remuneration and timeliness } \\
\text { - } \text { Reduction of the number of accidents what re- } \\
\text { - Sults in greater safety at work } \\
\text { - } \text { - Incrspectity of employment and better professional } \\
\text { - Social benefits } \\
\text { - Increase of motivation, satisfaction and en- } \\
\text { gagement of employees } \\
\text { - Increase of the identification of the employees } \\
\text { with an organization, better perception of an } \\
\text { organization } \\
\text { - Increase of innovativeness } \\
\text { - Developed organizational culture }\end{array}$ & $\begin{array}{l}\text { - Positive image of a company and improvement } \\
\text { of reliability } \\
\text { - Effective functioning in the society and } \\
\text { cooperation } \\
\text { - Increase of the loyalty of the hitherto clients } \\
\text { and the trust of the new ones } \\
\text { - Increased interest of potential investors } \\
\text { - Increased competitiveness }\end{array}$ \\
\hline
\end{tabular}

Source: Sznajder M. (2013).

While analysing the above presented benefits, it should be stated that both the internal and external benefits interact with each other. An enterprise cannot treat the internal and external environment separately, thus all the activities taken in the internal surroundings have the consequences among external stakeholders and vice versa. Therefore the benefits refer to the cooperation with the parties interested in the functioning of a company. The table 2 presents in detail the benefits of every stakeholder.

A separate type of benefits referring to the corporate social responsibility results from the nature of their acquisition. Thus we may distinguish financial benefits i.e. those that may be expressed in financial conversion and nonfinancial i.e. those which do not have their equivalent in money. While the first type may be additionally expressed in qualitative and quantitative way, the other one is considered merely in quantitative way. The matrix of correlations of the types of benefits and their indicators is presented in fig. 1. 
Table 2. Benefit for every stakeholder

\begin{tabular}{|c|c|c|}
\hline Stakeholders and owners & Employees & Dealers and suppliers \\
\hline $\begin{array}{l}\text { - Dividend, profit from } \\
\text { investment } \\
\text { - Increasing the value of } \\
\text { a company } \\
\text { - Creating innovations } \\
\text { - Reputation of an enterprise } \\
\text { - Financial benefits } \\
\text { - Improvement of management } \\
\text { - Minimisation of risk } \\
\text { - Higher investment level } \\
\text { - Increase of investors' interest } \\
\text { - Improvement of organisa- } \\
\text { - } \text { tional culture } \\
\text { - Pominance over competition }\end{array}$ & $\begin{array}{l}\text { - Increase of remuneration } \\
\text { - } \text { Realisation of other benefits } \\
\text { - } \text { empation of places of } \\
\text { - Training and development } \\
\text { - Enterprise's reputation } \\
\text { - Greater employment safety } \\
\text { - Stronger motivation } \\
\text { - Greater loyalty } \\
\text { - Higher efficiency } \\
\text { - Possibility of } \\
\text { - self-development } \\
\text { - Greater labour safety and } \\
\text { smaller rotation }\end{array}$ & $\begin{array}{l}\text { - } \text { Profit from sale of goods and } \\
\text { - } \text { Pervices } \\
\text { - Ortnership and loyalty } \\
\text { - Improvement of cooperation } \\
\text { - } \text { - Creation of innovations } \\
\text { - Improvement of } \\
\text { - Communication } \\
\text { - Increase of company's finan- } \\
\text { cial credibility }\end{array}$ \\
\hline Customers & Competition & National and regional communities \\
\hline $\begin{array}{l}\text { - Usefulness of purchased } \\
\text { - } \text { - Image of a company or brand } \\
\text { - } \text { Creation of innovations } \\
\text { - Improvement of life quality } \\
\text { - Improvement of society's } \\
\text { welfare } \\
\text { - Reduction of product's price } \\
\text { - Product's safety and } \\
\text { reliability } \\
\text { - Improvement of product's } \\
\text { - } \text { quality }\end{array}$ & $\begin{array}{l}\text { - Lack of losses resulting from } \\
\text { unfair competition } \\
\text { - Decrease of costs Decrease } \\
\text { of costs resulting from the } \\
\text { protection against unfair } \\
\text { practices } \\
\text { - Resourceful environment } \\
\text { - Increase of the welfare of } \\
\text { the society and at the same } \\
\text { time increase of its pur- } \\
\text { chase power } \\
\text { - Fair competition } \\
\text { - Legible and transparent } \\
\text { competitive activities }\end{array}$ & $\begin{array}{l}\text { - Income from taxes } \\
\text { - Income from other forms of } \\
\text { - Creation of workplaces } \\
\text { - Development of the region } \\
\text { - Improvement of the quality } \\
\text { of life } \\
\text { - Supporting transitions } \\
\text { - Environment protection } \\
\text { - Observation of legal norms }\end{array}$ \\
\hline
\end{tabular}

Source: as in the table 1. 


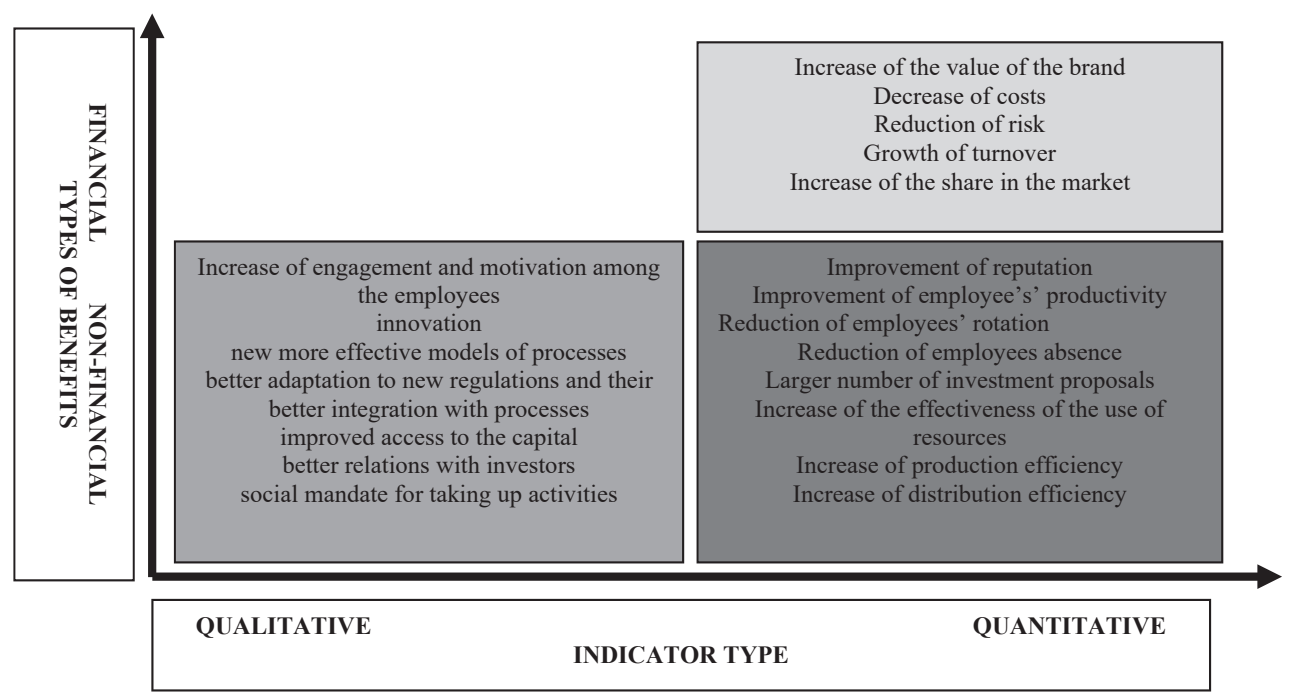

Figure 1. Summary of financial and non-financial benefits

Source: as in the table 1.

As demonstrated in the above matrix, non-financial benefits include:

1. Quantitative benefits which cover:

- increase of engagement and motivation among the employees

- innovation

- new more effective models of processes

- better adaptation to new regulations and their better integration with processes

- improved access to the capital

- better relations with investors

- social mandate for taking up activities

2. Quantitative representation on the other hand:

- reduction of employees' rotation and absence

- increase of production efficiency

- improvement of reputation

- increase of the effectiveness of the use of resources

- increase of distribution efficiency

Financial quantitative benefits include:

- increase of the value of the brand

- decrease of costs

- reduction of risk 
- growth of turnover

- increase of the share in the market

The main goal of enterprises is above all the increase of own profits and reduction of costs. However, when analysing the above mentioned benefits, it may be noticed that a company benefits more outside the financial area than in the money zone. This confirms the fact that the introduction of the CSR concept does not mainly influence the increase of profits of the owners of the companies, but it concentrates on the creation of proper relations in a given enterprise with the surroundings and this brings non-financial profits which also affect financial liquidity of this unit.

\section{Methodology of research}

Research methodology was based on the study called "CSR managers" carried out in Poland by the Responsible Business Forum (FOB) at the turn of May and July 2015. The aim of the study was to evaluate whether the managers notice the influence of the introduction of CSR on the functioning of the business. Managers dealing with CSR area on everyday basis participated in the research and the object of the research was composed of the companies from small and medium sized enterprises sector and large enterprises employing at least 250 employees. The latter constituted 65\% of the representatives of the study (all participants, $n=133$ ). The Responsible Business Forum is a think-and-do-tank type organization; it initiates and creates ventures for the Polish CSR. The mission of this organization is conducting business activity for the benefit of balanced development by way of supporting companies in the creation of responsible business, solving social problems; at the same time it becomes a platform where managers have the opportunity to exchange their experiences. The Responsible Business Forum Association analyses CSR by means of conducting periodical research in respect of the perception of the corporate social responsibility, introduction of this idea to the companies and cross-sectoral cooperation, elaborating its own reports and statements. Apart from that, it follows current analyses and reports of the studies carried out by other national and foreign institutions and describes them in its own publications (FOB 2015).

The second analysed material was a study carried out in September 2014 by KPMG company through a telephone interview. Large and medium (in respect of the profits and employent) sized companies participated in the study. The talks were mainly conducted with the managerial staff (13\%) 
and with the members of the management board (31\%) (research sample, $n=101)$. KMPG is an international net of audit and advisory companies, which implements its own strategy in Poland in a socially responsibe way. With its activities, the company supports local communities, takes care of the natural environment, initiates entrepreneurship in Poland, engages in the concpets connected with culture and above all promotes CSR (KPMG 2014).

\section{Results and discussion}

The analysis of the measurements of the Responsible Business Forum demonstrates that according to the researched persons, the activities within the scope of CSR have contributed in the recent years to the solution of specified social problems. Sixty five percent of respondents marked the answer "definitely yes" and "rather yes". Moreover, the managers indicated that the activities within the scope of environment protection constitute the most frequently solved social problem which does not demand large financial expenses and it brings measurable financial benefits and creates a positive image of a company.

Table 3. Impact of CSR on business functioning

\begin{tabular}{|l|r|l|}
\hline \multicolumn{2}{|c|}{$\begin{array}{c}\text { Have business contributed to the solution } \\
\text { of social problems in Poland in the recent years? }\end{array}$} & $\begin{array}{l}\text { What social problems have solved responsible business in } \\
\text { recent years? (the responses are ordered in decreasing order) }\end{array}$ \\
\hline Definitely yes & $11 \%$ & education \\
\hline Rather yes & $54 \%$ & social aid \\
\hline Rather no & $27 \%$ & environment protection \\
\hline Definitely no & $5 \%$ & promotion of healthy life style \\
\hline Hard to say & $3 \%$ & dialogue with the community \\
\hline & & charity, \\
\cline { 2 - 3 } & & fight with poverty \\
\cline { 2 - 3 } & & ethics in business \\
\cline { 2 - 4 } & & $\begin{array}{l}\text { Sample: person who claim that the business have con- } \\
\text { tributed to the solution of social problems in Poland in the } \\
\text { Sample: all respondents, } \mathrm{n}=133\end{array}$ \\
\hline
\end{tabular}

Source: own elaboration on the basis of: FOB (2015).

Whereas in the case of the question "if CSR influenced the improvement of the functioning of business?", $81 \%$ of respondents observes this influence in the way the companies are formed, paying more attention to the matters of ecology and needs of the society. 
Table 4. CSR and social problems

\begin{tabular}{|l|c|l|c|}
\hline $\begin{array}{c}\text { Did CSR influence the way of the functioning } \\
\text { of business in Poland? }\end{array}$ & \multicolumn{2}{c|}{ How did CSR influence the functioning of business in Poland? } \\
\hline Definitely yes & $16 \%$ & Change of the way of formation of companies & $62 \%$ \\
\hline Rather yes & $65 \%$ & Paying attention to ecology & $30 \%$ \\
\hline Rather no & $16 \%$ & Paying attention to the society & $29 \%$ \\
\hline Definitely no & $1 \%$ & Increase of ethics in the workplace & $6 \%$ \\
\hline Hard to say & $2 \%$ & Introduction of reporting on activities & $6 \%$ \\
\hline \multirow{5}{*}{ Sample: all respondents, $n=133$} & Increase of cooperation with surroundings & $6 \%$ \\
\cline { 3 - 4 } & & Charity & $4 \%$ \\
\cline { 2 - 4 } & Participation in social campaigns & $4 \%$ \\
\cline { 2 - 4 } & Other & $11 \%$ \\
\cline { 2 - 4 } & $\begin{array}{l}\text { Sample: persons who claim that CSR influenced the way } \\
\text { of the functioning of business, } n=104\end{array}$ \\
\hline
\end{tabular}

Source: as in the table 3.

The results of the study demonstrate that the managers distinctly see the positive effects of applying the idea of CSR in their own companies. The figure below presents the results most frequently indicated by the managers.

Table 5. Benefits of CSR activities

\begin{tabular}{|l|l|}
\hline \multicolumn{1}{|c|}{ Increase of the awareness level of the employees within the scope of ethics } & $74 \%$ \\
\hline Increase of the engagement level of the employees & $71 \%$ \\
\hline Increase of brand recognition as a responsible / balanced brand & $70 \%$ \\
\hline Improvement of relations with local communities & $69 \%$ \\
\hline Improvement of reputation & $62 \%$ \\
\hline Increase of the level of trust of the customers & $61 \%$ \\
\hline Introduction of new, innovative solutions (e.g. products, services, processes) & $47 \%$ \\
\hline Reduction of costs generated by business activity & $22 \%$ \\
\hline Reduction of the number of accidents at work & $22 \%$ \\
\hline Decrease of the level of rotation of the employees & $19 \%$ \\
\hline Other & $3 \%$ \\
\hline Hard to say & $2 \%$ \\
\hline No benefits were obtained & $0 \%$ \\
\hline
\end{tabular}

Source: as in the table 3.

The analysis of the telephone studies carried out by KPMG proved that according to the respondents, CSR has an actual influence on business activity. 
However, the directors and other employees were deeply convinced about this fact ( $81 \%$ of indications), whereas the highest-level managers expressed such opinion slightly more seldom (73\% of positive answers).

Table 6. The benefits of the CSR concept

\begin{tabular}{|l|c|}
\hline \multicolumn{2}{|c|}{$\begin{array}{c}\text { 77\% of respondents claim that the running of a business activity according } \\
\text { to the CSR concept positively influences the financial results of a company }\end{array}$} \\
\hline Improvement of the image in the market & $52 \%$ \\
\hline Increase of the acceptance of the surroundings & $36 \%$ \\
\hline Increase of the interest of contractors & $30 \%$ \\
\hline Increase of sale & $26 \%$ \\
\hline Increase of the interest of potential employees & $24 \%$ \\
\hline Reduction of costs & $23 \%$ \\
\hline Increase of the presence in mass media & $8 \%$ \\
\hline $\begin{array}{l}\text { N=100 } \\
\text { Respondents could indicate maximum two most important benefits }\end{array}$ \\
\hline
\end{tabular}

Source: own elaboration on the basis of: KMPG (2014).

Carried out study proved that the respondents are aware of the benefits resulting from the CSR concept and their observations, despite different positions held, are quite similar. The most frequently indicated benefit is the increase of profits and over a majority of the respondents claims that CSR activities contributed to the improvement of company's image. The enterprises become more aware of the fact that thanks to the communication with the surrounding, its acceptance is growing. By way of using a various kinds of tools applied in conducting socially responsible business, the company becomes more attractive in the view of contractors, both the regular and potential ones. Thanks to the activities promoted by the idea of CSR, an organization may acquire additional investors and develop resiliently. Through the increase of investments, introduction of innovations and actions for the benefit of environment protection and solving social problems, a company benefits from the sale of its own products. CSR is also an opportunity to reduce costs, what is the second of the main goals of the functioning of a unit in the market.

When analysing the studies carried out in 2015 and 2014, we noticed that the perception of the CSR concept has changed. Namely, in 2014 the studies performed by KPMG proved that for the owners of the companies, the most important chance connected with the introduction of CSR was the increase of the profits of their business activity. This presents that they perceived the CSR concept as a strategy of increasing financial profit. On the other hand the studies 
of the Responsible Business Forum reveal even greater awareness of the managers of this idea. Since the main advantages relate to the employees, what means that the management is aware of the role played by the employees in the functioning of an organization. The above mentioned studies also displayed that the units extended the knowledge of the communication of CSR activities with the surrounding. The companies pay attention to the fact that it is not sufficient to engage in charity actions or establish foundations which bring a lot of goods, but there must be a cohesion between the activities of the company, its values and conduct of the employees towards these values and all other matters communicated outside the company. The companies perceive CSR as a management concept, just as it is, allowing for the development of the value of an enterprise not only for the improvement of reputation or recognition of the brand which at the same time leads to the increase of profits, but above all during the time of developing this value, we must remember about the company's surrounding, its stakeholders, what constitutes the chief domain of the CSR concept. By applying CSR rules, a company has a better position in respect of its competitors, the trust towards the contractors increases and the contractors trust this organization. Differences are also visible in the number of indicated benefits, as in $\mathbf{2 0 1 5}$ more benefits were indicated. Thanks to the education within the scope of the activities, tools and the policies of responsible business concepts, the companies, societies and local authorities become more aware of the fact that CSR practices are nowadays indispensable for the proper communication between the organizations and their surroundings.

\section{Summary}

Summing up, social responsibility is the strategy of an enterprise taking into consideration social and environmental aspects transcending the obligations of the company. A proper implementation of CSR is distinguished by a long-term and reasoned running of a company in a socially responsible way. Moreover, it is worth mentioning that the implementation of CSR is connected not only with the obligations, but also with the benefits for a given company, material or ethical. The idea is important from the point of view of the society and ecologists, in particular today as the production is developing on a large scale and we encounter a numerous incidents connected with the contamination of the environment. CSR is also directly connected with the relations company-society and in particular with the employees. In today's market the value of human resources is invaluable, creativity and engagement constitute human's capital. Balanced business promoted by 
CSR requires also legal standards, transcending these standards as well as imposing higher ethical standards. Nevertheless the entrepreneurs take up the challenge as they gain competitive superiority in the market in which the number of the companies is constantly increasing and customer's expectations are also rising. The achievement of the goals set by CSR is incredibly ambitious and making decision about its implementation is not enough; CSR must be meticulously implemented in every level of the company management system. In general we may summarize that nowadays not being socially responsible is not profitable for the companies as it is a standard which is commonly applicable and globally implemented.

\section{References}

CIOP. Barcik A., Zarządzanie, społeczna odpowiedzialność a korzyści dla firmy. Górnośląska Wyższa Szkoła Handlowa (access 22.05.2017).

Gableta M. (2006). Zakres przedmiotowy gospodarowania potencjałem pracy. [In:] Gabela M. (ed.). Potencjał pracy przedsiębiorstwa. Wrocław: Wyd. AE.

Gadomska-Lila K. (2012). Społeczna odpowiedzialność biznesu wobec pracowników. Management and Business Administration. Central Europe, 2 (115).

ISO 26000:2010. Guidance on social responsibility. Chapter 2.

KMPG (2014). Społeczna odpowiedzialność biznesu: fakty a opinie (access 22.05.2017).

Madrak-Grochowska M. (2010). Społeczna odpowiedzialność biznesu - pomiędzy altruizmem a egoizmem przedsiębiorstw. Ekonomia i Prawo. Tom VI.

Odpowiedzialna Firma, http://www.odpowiedzialnafirma.pl/o-csr/korzysci-z-csr (access 22.05.2017).

Sznajder M. (2013). Korzyści z wdrożenia koncepcji społecznej odpowiedzialności biznesu (z uwzględnieniem koncepcji interesariuszy). Ekonomia i Zarządzanie, 2.

Zuzek D. K. (2012). Społeczna odpowiedzialność biznesu a zrównoważony rozwój Przedsiębiorstw. Zeszyty Naukowe MWSE w Tarnowie, 2 (12).

Wolak-Tuzimek A. (2016). Benefits of introducing the concept of corporate social responsibility to enterprises, Central European Review of Economics \& Finance, Vol. 14, No. 4.

KPMG, https://www.home.kpmg.com/pl/pl/home.html (access 22.05.2017).

PKN. (2013). https://www.pkn.pl/informacje/2013/09/iso-26000 (access 22.05.2017).

FOB. (2015). Menadżerowie CSR (access 22.05.2017).

MDG. (2014). Społeczna odpowiedzialność biznesu (access 22.05.2017). 